\title{
Analisis Muatan Kajian Gender pada Buku Teks Pendidikan Kewarganegaraan di Perguruan Tinggi
}

\author{
Nurul Febrianti ${ }^{\text {a, }}{ }^{*}$, Aim Abdulkarim ${ }^{\text {b, } 2}$, Elly Malihah ${ }^{\text {c, } 3}$, Susan Fitriasari ${ }^{\text {d,4 }}$ \\ a,b,c,d Universitas Pendidikan Indonesia, Indonesia \\ ${ }^{1}$ nurulfebrianti@upi.edu $*{ }^{2}$ aimabdulkarim@upi.edu; ${ }^{3}$ ellymalihah@upi.edu; ${ }^{4}$ susan_fitriasari@upi.edu \\ *korespondensi penulis
}

\author{
Informasi artikel \\ Received : \\ December10, 2019. \\ Revised : \\ January 18, 2020. \\ Publish : \\ January 31, 2020.
}

Kata kunci:

Kajian Gender

Pendidikan

Kewarganegaraan

Buku teks

Perguruan Tinggi

Keywords:

Gender Studies

Citizenship Education

Textbook

Higher Education

\begin{abstract}
ABSTRAK
Penelitian ini bertujuan untuk mendeskripsikan muatan kajian gender pada buku teks Pendidikan Kewarganegaraan di Perguruan Tinggi. Penelitian ini merupakan penelitian analisis konten dengan pendekatan kualitatif melalui tahap, yaitu pengadaan data, reduksi data, inferensi, dan analisis data. Sumber data penelitian adalah buku teks Pendidikan Kewarganegaraan yang dikeluarkan oleh Direktorat Jenderal Pembelajaran dan Kemahasiswaan Kemenristekdikti tahun 2016. Unit analisis adalah muatan kajian gender yang terkadung pada BAB yang berhubungan dan berkaitan dengan kajian gender dalam buku tersebut. Hasil penelitian yaitu: (1) Penyusunan buku teks dilihat dari parity gender dapat dikatakan disparity gender karena hanya terdapat tiga orang perempuan dari 12 orang penyusun buku teks. (2) Terdapat pembahasan tidak responsif gender dengan tidak mencantumkan organisasi perempuan dalam pergerakan nasional. (3) Ditemukan beberapa ilustrasi gambar yang bias gender dan mengakibatkan perspektif yang salah tentang gender stereotypes dan gender roles. (4) Kajian gender sebagai sebuah konten serta teks dan kurang pengintegrasian ke dalam beberapa bab yang beririsan dengan kajian gender seperti HAM, Demokrasi dan Rule of Law perlu disikapi karena Pendidikan Kewarganegaraan bersifat multifaced.
\end{abstract}

ABSTRACT

Analysis of the Gender Study Content in the Citizenship Education Textbook in Higher Education. This study aims to describe the content of gender studies in the Citizenship Education textbook in Higher Education. This research is a content analysis research with a qualitative approach through stages, namely data procurement, data reduction, inference, and data analysis. The source of the research data is the Citizenship Education textbook issued by the Directorate General of Learning and Student Affairs of the Ministry of Research and Technology in 2016. The unit of analysis is the content of gender studies contained in the chapter that relates to and is related to gender studies in the book. The results of the study are: (1) Compilation of textbooks seen from gender parity can be said to be gender disparity because there are only three women out of 12 textbook compilers. (2) There is an unresponsive discussion of gender by not including women's organizations in the national movement. (3) Found several illustrations of images that are gender-biased and lead to wrong perspectives on gender stereotypes and gender roles. (4) Gender study as a content and text and lack of integration into several chapters which intersect with gender studies such as Human Rights, Democracy and Rule of Law need to be addressed because Citizenship Education is multifaced.

Copyright $\odot 2020$ (Nurul Febrianti, Aim Abdul Karim, Elly Malihah, Susan Fitriasasi). All Right Reserved

How to Cite: Febrianti, N., Abdulkarim, A., Malihah, E., \& Fitriasari, S. (2020). Analisis Muatan Kajian Gender pada Buku Teks Pendidikan Kewarganegaraan di Perguruan Tinggi. Jurnal Inspirasi Pendidikan, 10(1), $70-77$.

This work is licensed under a Creative Commons Attribution-ShareAlike 4.0 International License. Allows readers to read, download, copy, distribute, print, search, or link to the full texts of its articles and allow readers to use them for any other lawful purpose. The journal hold the copyright. 


\section{Pendahuluan}

Pendidikan Kewarganegaran menjadi mata kuliah wajib umum (MKWU) yang wajib ditempuh oleh seluruh mahasiswa di Indonesia. Ketentuan tersebut tertuang dalam Undang-Undang Sistem Pendidikan Nasional Nomor 20 Tahun 2003 Pasal 37 ayat (2) yang menetapkan Pendidikan Kewarganegaraan sebagai salah satu mata kuliah yang wajib dimuat dalam kurikulum pendidikan tinggi berbarengan dengan Pendidikan Agama dan Bahasa. Konseskuensi dari amanat tersebut adalah setiap perguruan tinggi yang berada di Indonesia apapun program studinya harus menyelenggarakan mata kuliah tersebut. Hal ini dilakukan untuk membentuk karakter warga negara muda yang kelak akan menjadi warga negara dewasa yang paham akan hak dan kewajibannya sebagai warga negara Indonesia.

Pendidikan Kewarganegaan bersifat multifacet atau kajian lintas-bidang keilmuan. Menurut Winataputra secara substantif Pendidikan Kewarganegaraan utamanya disokong oleh ilmu politik dan ilmu-ilmu sosial, serta humaniora dan secara pedagogis diterapkan dalam dunia pendidikan (Winaputra, 2015.). Dalam buku teks Pendidikan Kewarganegaraan yang diterbitkan oleh Direktorat Jenderal Pembelajaran dan Kemahasiswaan Kemenristekdikti, telah menetapkan kurikulum serta kompetensi yang diharapkan setelah mahasiswa mempelajari Pendidikan Kewarganegaraan di perguruan tinggi. Meskipun terdapat pembahasan tentang demokrasi dan hak asasi manusia tetap masih belum mengerucut tentang pemahaman konsep gender dalam Pendidikan Kewarganegaraan (Febrianti, 2017).

Kajian gender diperlukan agar membentuk mahasiswa mengerti tentang kesetaraan gender yang juga menjadi salah satu agenda dari Sustainable Development Goals (SGDs) yang dikeluarkan oleh Perserikatan Bangsa-Bangsa (Johnston, 2016). Muara dari mempelajari Pendidikan Kewarganegaraan yakni membuat mahasiswa mampu mengerti dan memahami hak dan kewajibannya sebagai warga negara, dengan kata lain berfokus pada citizens' behavior (Mattei \& Broeks, 2018). Dalam membentuk perilaku warga negara dalam proses pembelajaran, salah satu upaya yang dilakukan melalui buku teks atau bahan ajar yang tersedia. Namun, bagaimana isi dalam buku teks tersebut terhadap pengetahuan tentang kajian gender yang seharusnya didapatkan oleh mahasiswa saat mempelajari Pendidikan Kewarganegaraan.

Buku teks Pendidikan Kewarganegaraan yang diterbitkan Kemenristekdikti perlu dibedah apakah isi konten yang diajarkan dapat membentuk pengetahuan mahasiswa tentang gender secara utuh. Hal ini penting karena pengetahuan tentang gender dapat dipelajari lewat Pendidikan Kewarganegaraan dalam pembahasan tentang Demokrasi, Hukum dan Hak Asasi Manusia, yang mana dapat mempromosikan gender equality (Arnot, 2015). Kekayaan keragaman isu-isu yang diusulkan dalam buku memungkinkan mahasiswa untuk lebih siap untuk mempromosikan dan, akibatnya, mengevaluasi program-program sensitif gender dalam Pendidikan Tinggi, dengan cara ini mendukung strategi nasional dan internasional di mana, akhirnya, studi gender dapat menandakan kehadiran yang bermakna (Policek, 2013). Oleh karena itu, tujuan penelitian ini adalah memberi masukan dan kritik terhadap konten isi sejauh mana muatan kajian gender dalam buku teks Pendidikan Kewarganegaraan.

\section{Metode}

Penelitian ini menggunakan metode analisis konten dengan pendekatan kualitatif. Penelitian ini menganalisis muatan kajian gender pada buku teks Pendidikan Kewarganegaraan di Perguruan Tinggi yang telah diterbitkan oleh Direktorat Jenderal Pembelajaran dan Kemahasiswaan Kemenristekdikti. Pengumpulan data dalam penelitian ini dilakukan dengan analisis isi dan pencatatan secara cermat terhadap buku teks Pendidikan Kewarganegaraaan. Instrumen utama dalam penelitian ini adalah peneliti sendiri dengan cara memasukkan ke dalam rubik analisis yang telah dibuat beredasarkan muatan kajian gender pada Bab yang akan dianalisis. Prosedur dalam penelitian ini analisis konten terdiri dari empat langkah, yaitu pengadaan data, inferensi, dan analisis data. Dalam tahap pengadaan data akan dilakukan tiga bagian yakni penentuan unit analisis, pengutan sampel, dan pencatatan. Reduksi data dilakukan dengan menghilangkan bagian atau kajian yang tidak sesuai dengan hal yang akan dianalisis dalam kajian gender. Terakhir, inferensi dilakukan dengan cara menggunakan kriterian penentuan muatan kajian gender yang terdapat dalam buku teks. Validasi untuk keabsahan data menggunakan validasi semantik yang digunakan untuk mengerahui kesesuaian analisis kategori teks 
dengan konteks yang dipilih. Selanjuntya reabilitas instrument menggunakan reabilitas stabilitas dan reabilitas replikabilitas. Tahap analisis data dilakukan dengan menggunakan teknik analisi kualitatif.

\section{Hasil dan Pembahasan}

Buku teks Pendidikan Kewarganegaraan yang diterbitkan oleh Direktorat Jenderal Pembelajaran dan Kemahasiswaan Kemenristekdikti terdapat 10 Bab, yaitu: (1) Hakikat Pendidikan Kewarganegaraan; (2) Identitas Nasional; (3) Integrasi Nasional; (4) UUD NRI Tahun 1945 dan Konstitusi; (5) Hak dan Kewajiban Warga Negara; (6) Demokrasi di Indonesia; (7) Penegakan Hukum; (8) Wawasan Nusantara; (9) Ketahanan Nasional; dan (10) Project Citizen. Bab yang telah dianalisis muatan kajian gender pada buku teks Pendidikan Kewarganegaraan adalah Hakikat Pendidikan Kewarganegaraan, UUD NRI Tahun 1945 dan Konstitusi, Hak dan Kewajiban Warga Negara, Demokrasi di Indonesia, dan Penegakan Hukum. Pemilihan Bab tersebut berdasarkan kajian yang beririsan dengan gender atau kesetaraan gender.

Hasil analisis diawali dengan gender parity dalam penyusuan buku teks Pendidikan Kewarganegaraan atau jumlah penulis atau penyusun buku tersebut. Ditemukan dalam penyusunan buku ajar ini terdiri dari 12 orang dan hanya menjumpai 3 orang perempuan dan selebihnya laki-laki. Dalam pembahasan tiap bab juga tidak jarang ditemui dari segi pengutipan lebih dominan para ahli laki-laki dibandingkan perempuan.

Bab pertama tentang Hakikat Pendidikan Kewarganegaraan, muatan kajian gender yang dapat dilihat ada pada ilustrasi gambar yang disuguhi. Dalam bab ini penyusun mencoba mengungkapkan bagaimana peran Pendidikan Kewarnegaraan sebagai upaya membentuk mahasiswa sebagai calon professional menjadi warga negara yang baik dan cerdas. Terlihat ilustrasi perempuan yang diasosiasikan menjadi seorang guru dan di halaman berikutnya mengasosiasikan laki-laki menjadi seorang Tentara Nasional Indonesia (TNI). Selanjuntya, dalam bab ini banyak menceritakan bagaimana perjalanan bangsa Indonesia menjadi negara yang merdeka. Dalam penjelasannya mengemukakan peran organisasi-organisasi pergerakan kemerdekaan Indonesia seperti Budi Utomo, Sarekat Islam, Indische Partij, dan lain-lain yang menunjukkan dominasi laki-laki. Nyatanya, pergerakan nasional juga diwakili oleh organisasi-organisasi perempuan seperti Putri Mardika, Aisiyiah, Kerajian Amai Setia (KAS), dan lain-lain.

Bab kedua yang dianalisis mempelajari tentang UUD NRI Tahun 1945 dan Konstitusi. Dalam bab ini menjelaskan konsep citizenship dimana hubungan negara dengan warga negara di atur dalam sebuah konstitusi. Pembahasan tentang kekuasaan raja sebagai pemimpin negara dan pembahasan citizenship yang sangat maskulin sehingga dianggap tidak responsif gender. Lebih lanjut lagi dalam pembahasan bab ini kembali absennya peran perempuan saat membahas unjuk rasa yang dilakukan pada tahun 1998 menuntut lengsernya rezim orde baru. Pemilihan kata mahasiswa dan pemuda hingga dua kali penyebutan dalam halaman 101 sangat tidak responsif gender dan mengabaikan peran mahasiswi dan pemudi yang juga turun ke jalan. Namun, pada bagian akhir terdapat ilustrasi gambar yang dapat diartikan sebagai kesetaraan gender, yakni terdapat gambar laki-laki dan perempuan dengan kondisi di dalam sebuah pasar. Hal ini menggambarkan bahwa pasar bukan hanya untuk perempuan melaikan juga laki-laki.

Bab Hak dan Kewajiban Warga Negara tidak ditemukan kajian gender yang signifikan. Pada bab awal penyusun menjelaskan kedudukan warga negara dengan tidak membedakan laki-laki dan perempuan. Selanjutnya dalam bab ini penyusun pun tidak membedakan hak dan kewajiban laki-laki dan perempuan dalam konsep berbangsa dan bernegara. Bab hak dan kewajiban banyak membahasa tentang hak termasuk HAM, namun tidak ditemukan pembahasan gender dalam bab ini.

Bab demokrasi dalam buku teks Pendidikan Kewarganegaraan menceritakan tentang sejarah demokrasi yang berasal dari Yunani. Dalam buku teks terhitung dua (2) kali menyebut 'minoritas kaum laki-laki dewasa' pada halaman 153 dan 'kaum laki-laki merdeka' pada halaman 160. Maknanya adalah bahwa hak perempuan dalam berdemokrasi saat itu tidak dimiliki dan ini dapat disoroti oleh para pengajar Pendidikan Kewarnegaraan. Bab demokrasi juga panjang menjelaskan tentang keterwakilan rakyat oleh Majelis Permusyawaratan Rakyat (MPR), Dewan Perwakilan Rakyat (DPR), dll. Namun tidak ada misalnya penjelasan tentang 30\% kuota perempuan dalam parlemen menjadi ketentuan dalam pemilihan umum. 
Bab terakhir dalam penelitian analisis isi dalam buku Pendidikan Kewarganegaraan adalah terkait Penegakan Hukum di Indonesia. Sama halnya dengan bab hak dan kewajiban warga negara, tidak ditemukan muatan yang berbau gender pada bab ini. Peneliti hanya menemukan sebuah ilustrasi gambar pada halaman 197 yang membahasan terkait Kehakiman. Pada gambar tersebut terlihat 3 orang hakim yang sedang melakukan persidangan. Seperti pada bab awal bahwa ini dapat diidentikan bahwa profesi hakim merupakan profesi laki-laki bukan perempuan.

Telah ditemukan beberapa hal yang dapat dianalisis dalam buku teks Pendidikan Kewarganegaraan yang diterbitkan oleh Direktorat Jenderal Pembelajaran dan Kemahasiswaan Kemenristekdikti yang berkaitan dengan muatan gender. Muatan gender dalam analisis penelitian ini bukan hanya melihat gender sebagai konten, tetapi juga gender dalam berbagai perspektif seperti gender bias, gender equality, gender parity, gender stereotypes dan gender roles dalam tiap gambar ilustrasi, narasi atau konten dalam teks.

Sebelum membahas bagian perbab yang telah dianalisi, di awal telah ditemukan dalam penyusunan buku tersebut sangat tidak seimbang bila dilihat dari konsep gender parity atau keseimbangan gender. Gender parity adalah dimana terdapat keseimbangan terhadap jumlah antara laki-laki dan perempuan dalam bidang apapun. Gender parity mencerminkan kesetaraan formal, dalam hal akses dan partisipasi dalam pendidikan. Kesetaraan formal juga dapat dipahami sebagai kesetaraan yang didasarkan pada gagasan kesamaan laki-laki dan perempuan, di mana aktor laki-laki dianggap sebagai norma (Subrahmanian, 2005). Jumlah perempuan yang berjumlah 3 orang dirasa kurang mewakili terhadap salah satu gender dan bisa saja berakibat dengan isi konten buku teks Pendidikan Kewarganegaraan dan ini dapat dikatakan sebagai disparity gender.

Dalam bab pertama tentang Hakikat Pendidikan Kewarganegaeaan ditemukan ilustrasi gambar terkait profesi bahwa perempuan yang diasosiasikan menjadi seorang guru dan di halaman berikutnya mengasosiasikan laki-laki menjadi seorang TNI. Dalam konsep gender dapat dianalisis berdasarkan gender stereotypes yang maknanya bahwa profesi sebagai TNI diindikasi merupakan profesi 'lakilaki' dan profesi guru diindikasi sebagai profesi bagi gender 'perempuan'. Gender stereotypes muncul akibat dari perspektif gender yang kurang tepat sehingga membeda-bedakan antara laki-laki dan perempuan dalam hal ini dicontohkan profesi guru dan TNI. Mollaeve menyatakan bahwa gender stereotypes adalah gagasan tentang fungsi sosial apa yang dilakukan oleh perempuan dan laki-laki. Pengaruh gender stereotypes sangat terlihat ketika subjek meninggalkan peran stereotip yang ditentukan (Mollaeva, 2018).

Dalam penyusunan buku Manusia dan Majarakat Baru Indonesia yang menjadi buku pertama terkait tentang Pendidikan Kewarganegaraan juga terlihat sama seperti buku teks Pendidikan Kewarganegaraan ini yang dikeluarkan oleh Kemenristekdikti. Bahkan semua disusun oleh laki-laki, yaitu Mr. Soepardo, Mr. M. Hoetaoeroek, Soeroyo Warsid, Soemardjo, Chalid Rasjidi, Soekarno, dan Mr. J.C.T. Simorangkir pada halaman 13 dalam buku teks tersebut. Masih pada bab Hakikat Pendidikan Kewarganegaraan, teori-teori Pendidikan Kewarnegaraan juga masih didominasi oleh laki-laki dalam konsep yang dijelaskan. Kurangnya ahli perempuan dalam Pendidikan Kewarnegaraan disinyalir membuat kajian dan konsep Pendidikan Kewarganegaraan tidak mengarusutamakan gender atau tidak responsif gender. Instruksi Presiden tahun 2000 tentang Pengarusutamaan Gender (PUG) dalam Pembangunan Nasional menjadi jelas dari segi aspek yuridis bahwa PUG juga menjadi agenda nasional Republik Indonesia.

Kajian dan teori-teori besar citizenship sebagai sebuah konsep telah lama dikritik oleh Sylvia Walby. Walby mengkritik bahwa konsep citizenship absen akan kajian gender, Ia mengatakan, "gender is absent from many discussion of citizenship" (Walby, 1994). Teori besar citizenship seperti yang dibawa oleh T.H. Marshall, Michael Mann, dan Bryan Turner dalam kritik Walby terlihat sangat maskulin atau untuk 'laki-laki' dalam bernegara dan berpolitik. Maka tidak mengherankan bahwa tradisi ini masih terus berlangsung sampai pada konsep Pendidikan Kewarganegaraan yang absen juga akan kajian gender di dalam muatannya. Hal ini dapat dilihat pada pembahasan pergerakan nasional saat Indonesia ingin merdeka yang tidak disebutkannya organisasi-organisasi perempuan seperti Putri Mardika, Aisiyiah, Kerajian Amai Setia, dan lain-lain.

Dalam pergerakan kemerdekaan Indonesia kita cukup mengenal beberapa organisasi seperti Budi Utomo, Sarekat Islam, Indische Partij, dan lain-lain. Organisasi-organisasi tersebut lahir sebagai 
gerakan nasional yang menginginkan Indonesia terlepas dari imperialisme penjajahan, menyuarakan dalam bidang pendidikan, dan memajukan semangat perdagangan masyarakat Indonesai saat itu. Organisasi-organisasi perempuan seperti Putri Mardika, Aisiyiah, Kerajian Amai Setia juga tidak dapat dilupakan begitu saja. Perkumpulan organisasi yang dimotori perempuan bukan hanya menginginkan Indoesia merdeka namun juga menyuarakan kesetaraan. Putri Mardika yang berdiri pada tahun 1912 dalam pergerakkannya menginginkan kemerdekaan serta kehidupan yang lebih baik serta mengupayakan memperluas ruang gerak untuk para perempuan dan bukan lagi terbelenggu dengan perkara adat istiadat yang membatasi para perempuan (Diniyanti, 2017). Putri Mardika merupakan organisasi keputrian dari pada organisasi Budi Utomo.

Selain Putri Mardika juga terdapat organisasi Aisiyah di bawah naungan organisasi Muhammdiyah pada pergerakan perempuan dalam masa penjajahan. Organisasi Aisiyah yang lahir di Kauman, Yogyakarta dalam penelitian yang dilakukan oleh Latifah Hayati menemukan bahwa peran Aisiyah menanamkan nilai-nilai kemuhammadiyahan kepada keluarga-keluarga di Kampung Kauman seperti nilai mengembangkan kehidupan pribadi, nilai berkeluarga, niali bermasyarakat, nilai berorganisasi dan beramal usaha (Hayati, 2008). Aisiyah bergerak dalam bidang sosial, agama, pendidikan dan kesehatan yang sampai hari ini masih terus memperjuangkan kesetaraan dan bergerak dalam bidang-bidang tersebut. Kerajinan Amai Setia (KAS) adalah perkumpulan yang berada di Sumatera Barat yang dipelopori oleh Rohana Kuddus. KAS didirikan untuk membantu perekonomian perempuan pada saat itu yang menurut Rohana Kuddus upaya perempuan dalam menghadapi kekerasan terhadap perempuan maka perempuan harus memiliki dua kekuatan yakni (1) melalui pendidikan dan ekonomi; (2) melalui media yang menyebar luas ke seluruh penjuru (Sari, 2016). Gerakan KAS ini menggagas bahwa perempuan harus mandiri dari segi perekonomian hingga cerdas dalam berpikir, sehingga dapat melawan kekerasan yang tertuju pada dirinya.

Bab Undang-Undang Negara Republik Indonesia Tahun 1945 dan Konstitusi merupakan bab yang diawal pembahasan menjelaskan hubungan antara warga negara dan negara yang dilindungi dalam Konstitusi. Dalam buku teks Pendidikan Kewarganegaaran, terminologi warga negara dijelaskan secara holistik dengan tidak membedakan peran antara warga negara laki-laki dan perempuan. Pada bab ini, penjelasan hak warga negara dan HAM dicampur dalam satu subbab pembahasan dan tidak terlalu ketara pemisahan antara kedua ini. Bila Hak Asasi Manusia memiliki bab yang berdiri sendiri, maka akan sangat mudah mengintegrasikan kajian gender dalam bab HAM. Arikel yang ditulis oleh Fredman dan Goldbaltt dan dipublish oleh United Nation Women menjelaskan bahwa hakikat dari hak asasi manusia menyatakan bahwa setiap manusia berhak atas semua hak dan kebebasan tanpa perbedaan apa pun, seperti ras, warna kulit, jenis kelamin, bahasa, agama, pendapat politik atau lainnya, asal kebangsaan atau sosial, harta benda, kelahiran atau lainnya status (Fredman \& Goldblatt, 2015).

Dalam kajian hak asasi manusia bila ingin mengintegrasikan kajian gender di dalamnya tentu merupakan hal yang substantif. Hal demikian mengingat bahwa Indonesia salah satu negara yang juga meratifikasi konvesi $\mathrm{PBB}$ tentang penghapusan kekerasan dan diskriminasi terhadap perempuan. The Convention on the Elimination of All Forms of Discrimination against Women (CEDAW) merupakan konvesi PBB yang juga diratifikasi oleh Indonesia dengan beberapa negara lainnya dan konsekuensinnya adalah Pemerintah sebagai penyelenggara negara wajib mempromosikan gender equality dan menghapuskan segala bentuk diskriminasi terhadap perempuan. Wujud usaha yang dilakukan Pemerintah salah satunya berupa Instruksi Presiden tahun 2000 tentang Pengarusutamaan Gender (PUG) dalam Pembangunan Nasional. Maka, seharusnya mata pelajaran/kuliah Pendidikan Kewarganegaraan menjadi salah satu sarana dalam mempromosikan kajian gender karena memiliki irisan yang kuat dengan HAM yang dibahas dalam buku teks. Patut dipahami bahwa batasan kajian gender pada penelitian ini adalah terbatas pada pembahasan peran, hak, dan kewajiban laki-laki dan perempuan dalam kehidupan berbangsa dan bernegara, khusunya di Indonesia melalui Pendidikan Kewarganegaraan. Untuk menghindari komplikasi, gender selain laki-laki dan perempuan tidak dibahas dalam penelitian ini, seperti pergerakan kaum LGBTQA (lesbian, gay, bisexual, transgender, queer, and asexual) yang kajian tersebut juga termasuk dalam gender studies.

Bab demokrasi seperti yang telah ditemukan dalam hasil penelitian bahwa di awal menjelaskan materi praktik demokrasi yang dilakukan negara Yunani. Demokrasi yang dilakukan oleh negara 
Yunani dengan tidak memasukan perempuan dan budak dalam partisipasi bernegara saat itu tidak disoroti sebagai pembahasan yang menyinggung kesetaraan. Walaupun dalam buku teks menyebutkan secara teks seperti 'minoritas kaum laki-laki dewasa' pada halaman 153 dan 'kaum laki-laki merdeka' pada halaman 160, namun tidak menjelaskan mengapa perempuan tidak hadir dalam proses demokrasi tersebut. Dalam tulisan yang berjudul Women in The Law of Democratic Athens yang ditulis oleh Ketevan Nadareishvili mengungkapkan bahwa dalam hukum Athena, perempuan tidak berstatus makhluk yang sepenuhnya otonom sehingga dianggap bukan atau tidak memiliki status warga negara (Nadareishvili, 2015). Pada pembahasannya, bab demokrasi seharusnya dapat mengintegrsikan kajian gender saat membahas tentang proses demokrasi yang dilakukan oleh Yunani yang merupakan negara pertama pengusung demokrasi. Hal ini sejalan dengan pendapat Beer bahwa demokrasi harus dianggap sebagai fenomena historis dengan konsekuensi yang berkembang selama bertahun-tahun dan decade bahwa partisipasi perempuan harus dimasukkan sebagai komponen penting dari demokrasi (Beer, 2009).

Di Indonesia seperti yang telah tertuang di atas bahwa pergerakan organisasi perempuan pada masa pra kemerdekaan menjadi awal gagasan dan gerakan terhadap memperjuangkan kesetaraan. Upaya yang dilakukan Pemerintah misalnya dapat dilihat dari Kementerian Pemberdayaan Perempuan dan Perlindungan Anak yang memiliki strategi dan agenda mewujudkan kesetaraan gender. Tiga kementerian seperti Kementerian Hukum dan Hak Asasi Manusia, Kementerian Pemberdayaan Perempuan dan Perlindungan Anak, dan Kementerian Dalam Negeri mengeluarkan buku berjudul Parameter Kesetaraan Gender dalam Pembentukan Peraturan Perundang-Undangan (Wardhani, 2012). Hari ini kita dapat melihat gaung kesetaraan gender di Indonesia menjadi perhatian dengan beberapa kebijakan dan peraturan juga mengutamakan Pengarusutamaan Gender (PUG). Kendati demikian masih terjegalnya pengesahan Rancangan Undang-Undang Keadilan dan Kesetaraan Gender (RUU KKG) juga menjadi perhatian karena dianggap kontroversi dan tidak sesuai dengan nilai-nilai di Indonesia.

Bab demokrasi juga dapat mempromosikan kesetaraan gender saat membahasan keterwakilan perempuan dalam Legislatif yang faktanya sampai sekarang tidak pernah terpenuhi persentase sebesar $30 \%$ di Indonesia. Pemerintah telah mengeluarkan beberapa peraturan dalam bentuk Undang-undang untuk memenuhi keterwakilan perempuan dalam parlemen. Peraturan tersebut tercantum dalam Undang-undang Nomor 31 Tahun 2002 tentang Partai Politik dan Undang-Undang Nomor 12 Tahun 2003 tentang Pemilihan Umum dan Undang-Undang Nomor 2 Tahun 2008 tentang Partai Politik dan Undang-Undang Nomor 10 Tahun 2008 tentang Pemilihan Umum Anggota Dewan Perwakilan Rakyat, Dewan Perwakilan Rakyat Daerah. Namun, sampai saat ini keterwakilan perempuan dalam parlemen belum pernah menyentuh angka 30\%. Perempuan dibutuhkan dalam parlemen demi pergerakan untuk memperjuangkan isu-isu perempuan dalam kebijakan publik (Pinto et al., 2013). Maka, bila ingin gender equality atau isu-isu perempuan dalam berbangsa dan bernegara terakomodir dengan baik, sudah semestinya keterwakilan $30 \%$ perempuan dalam parlemen harus terwujud.

Bab terakhir dalam analisis buku teks Pendidikan Kewarganegaraan yakni Penegakan Hukum di Indonesia. Pada bab Penegakan Hukum di Indonesia yang dapat disoroti adalah ilustrasi gambar yang mengidentikkan profesi hakim. Terlihat 3 orang hakim laki-laki dalam sebuah persidangan pada buku teks Pendidikan Kewarganegaraan. Dalam buku yang ditulis oleh Joanne Conaghan yang berjudul Law and Gender, terdapat bagian yang membahas mengenai between law and gender. Dalam penjelasannya Ia mengatakan bahwa banyak scholars dan feminist yang mengatakan bahwa 'law is male' (Conaghan, 2013). Hal ini terjadi akibat dari produk hukum yang dibuat dan membuat begitu maskulin, selanjutnya dari segi pembahasan dalam Bahasa Inggris yang menggunakan kata 'man' yang memiliki 2 makna yaitu laki-laki dan manusia secara general. Maka Ia menyinggung bahwa hukum tentu terlihat begitu gender dalam konteks mempertimbangkan apakah dan sejauh mana gender itu dikategorikan signifikansi dalam hukum yang tentu berguna untuk mengeksplorasi dimensi historis, ideologis, dan/atau simbolik untuk klaim semacam itu. (Conaghan, 2013).

Bab Penegakan Hukum di Indonesia semesterinya juga dapat mempromosikan gender equality dengan memberikan contoh kasus dalam pembahasan. Contoh kasus dalam buku teks Pendidikan Kewarnegaraan kebanyakan berkaitan dengan pembayaran pajak. Ya, sebagai warga negara yang baik tentu harus turut serta dalam pembangunan nasional dengan membayar pajak, namun dengan contoh 
yang terlalu banya di tiap bab tentu tidak imbang untuk membuka pembahasan yang lebih luas. Penegakan Hukum atau rule of law yang diajarkan dalam Pendidikan Kewarganegaraan sangat berisian dengan HAM. Negara yang menganut konsep rule of law, HAM merupakan salah satu yang menjadi indikatornya ditambah juga negara demokrasi. Maka, lingkaran HAM, Demokrasi, dan Rule of Law pada dasarnya sangat berhubungan dengan gender. Contoh kasus yang linked terhadap ketiga pembahasan tersebut dan berkaitan denger gender adalah Kasus Marsinah. Seorang aktivis buruh perempuan yang sampai saat ini kasusnya masih menjadi pertanyaan besar.

Pendidikan Kewarganegaraan yang memiliki ciri multifaced tidak seharusnya melupakan kajian gender untuk dipelajari dan dibahas. Sistem pemerintahan Indonesia yang demokratis juga menjadi konsekuensi bahwa kesetaraan gender juga memiliki tempat untuk diperjuangkan. Seperti yang dikatakan oleh Gaylard bahwa sekolah/perguruan tinggi berkewajiban mempromosikan kesetaraan gender, karena mengajari terkait dengan isu-isu gender dapat membuka mata perempuan dengan hal baru yang dahulu mungkin dianggap bukan untuk perempuan dan mengajari laki-laki tentang kesetaraan (Gaylard, 2015). Kajian gender bukan hanya berbicara tentang perempuan saja atau lakilaki saja, kajian ini membahas bagaimana akhirnya setiap warga negara memiliki kesempatan dan peran yang sama dalam berbagai bidang seperti pendidkan, politik, ekonomi, dll tanpa melihat jenis kelamin dan dapat bekerjasam secara baik.

Maka, dengan mengintegrasikan kajian gender ke dalam Pendidikan Kewarganegaraan melalui buku teks diharapkan dapat membantu warga negara muda memahami kesetaraan gender. Warga negara muda (young citizen) tidak lagi memiliki gender strereotypes terhadap warga negara lain atau melihat kemampuan seseorang berdasarkan gender yang dapat menimbulkan diskriminatif. Peran berdasarkan gender (gender roles) dalam bingkai berbangsa dan bernegara juga akan disikapi dengan baik, sehingga (misal) para warga negara muda tidak lagi menganggap bahwa hanya laki-laki yang memiliki kemampuan memimpin. Seperti yang dikatakan oleh Bandura terkadang menggambarkan pria sebagai pemimpin dan figur otoritas di sisi lain menggambarkan wanita sebagai bawahan (Bandura, 1997).

Buku teks sebagai sarana dalam proses pembelajaran berperan penting dalam memberikan ilmu, konsep, data hingga informasi kepada peserta didik. Maka, buku teks Pendidikan Kewarganegaraan juga memiliki peran penting mempromosikan peserta didik menjadi warga negara yang baik dan cerdas salah satunya memahami mengenai kesetaraan gender. Para pengajar Pendidikan Kewarganegaraan juga diharapkan dapat mengintegrasikan nilai-nilai kesetaraan gender dalam tiap bab yang terdapat dalam buku teks Pendidikan Kewarganegaraan di Perguruan Tinggi.

\section{Simpulan}

Berdasakan hasil penelitian dan pembahasan kajian muatan gender pada buku teks Pendidikan Kewarnegaraan di Perguruan Tinggi, maka dapat ditarik beberapa kesimpulan. Pendidikan Kewarnegaraan merupakan mata kuliah yang bersifat multifaced sehingga sewajarnya kajian gender menjadi bagian dari pembahasan yang terintegrasi di beberapa bab seperti HAM, Demokrasi dan Rule of Law. Disparity gender dalam penyusunan buku teks Pendidikan Kewarganegaraan yang dapat dilihat dari hanya terdapat 3 orang perempuan dari 12 orang penyusun buku teks. Ditemukan juga beberapa penjelasan yang tidak responsif gender seperti alfanya menyebutkan pergerakan organisasi perempuan pada saat pra kemerdekaan dan pergerakan pemudi dan mahasiswi dalam pergerakan Mei 1998. Konten seperti ilustrasi gambar yang dapat menimbulkan gender stereotypes dan gender roles yang salah persepsi, seperti profesi yang diasosiasikan profesi laki-laki dan perempuan, hal demikian juga menghadirkan bias gender. Kajian gender sebagai sebuah konten serta teks dan kurangnya pengintegrasian ke dalam beberapa bab yang seharusnya beririsan dengan kajian gender seperti HAM, Demokrasi dan Rule of Law perlu disikapi.

\section{Referensi}

Arnot, M. (2015). Gender, education and citizenship. Education for All Global Monitoring Report as background information to assist in drafting the 2003/4 report.

Bandura, A. (1997). Theoretical Perspectives: the nature of human agency. Self-Efficacy: The Exercise of Control. https://doi.org/10.1007/SpringerReference_223312 
Beer, C. (2009). Democracy and gender equality. Studies in Comparative International Development, 44(3), 212-227. https://doi.org/10.1007/s12116-009-9043-2

Conaghan, J. (n.d.). Law and Gender. Oxford Univerity Press: United Kingdom.

Diniyanti, R. (2017). Gerakan Emansipasi Perempuan di Awal Abad Ke-20: Poetri Mardika 19121919.

Febrianti, N. (2017). Pendidikan Kewarganegaraan: Mewujudkan Kesetaraan Gender. Prosiding Konferensi Nasional Kewarganegaraan III 11 November 2017, Universitas Ahmad Dahlan, Yogyakarta

Fredman, S., \& Goldblatt, B. (2015). Gender Equality and Human Rights. UN Women. https://doi.org/10.2307/j.ctvw04d83.16

Gaylard, B. (2015). Genderschools.com - Teachers for change: Putting gender in the curriculum. Agenda, 29(3), 60-65. https://doi.org/10.1080/10130950.2015.1080464

Hayati, L. (2008). Peran 'Aisyiah Dalam Internalisasi Nilai-Nilai Muhammadiyah di Kampung Kauman Yogyakarta.

Johnston, R. B. (2016). Arsenic and the 2030 Agenda for sustainable development. Arsenic Research and Global Sustainability - Proceedings of the 6th International Congress on Arsenic in the Environment, AS 2016, 12-14. https://doi.org/10.1201/b20466-7

Mattei, P., \& Broeks, M. (2018). From multiculturalism to civic integration: Citizenship education and integration policies in the Netherlands and England since the 2000s. Ethnicities, 18(1), 2342. https://doi.org/10.1177/1468796816676845

Mollaeva, E. A. (2018). Gender stereotypes and the role of women in higher education (Azerbaijan case study). Education and Urban Society, 50(8), 747-763. https://doi.org/10.1177/0013124517713613

Nadareishvili, K. (2015). Women in the law of democratic athens, (January 2003). https://www.researchgate.net/publication/270587729

Pinto, T., Nogueira, C., Vieira, C., Silva, I., Saavedra, L., João, M., ... Tavares, T.-C. (n.d.). Education Guide Gender and Citizenship 3 rd Cycle Education Guide: Gender and Citizenship 3 rd Cycle.

Policek, N. (2013). From gender studies to gender IN studies: case studies on gender-inclusive curriculum in higher education, Bucharest, UNESCO-CEPES Studies on Higher Education 66, 3739.

Sari, S. R. (2016). Dari Kerajinan Amai Setia Ke Soenting Melayoe Strategi Rohana Kuddus Dalam Melawan Ketertindasan Perempuan Di Minangkabau. Kafa `ah: Journal of Gender Studies, 6(2), 235. https://doi.org/10.15548/jk.v6i2.148

Subrahmanian, R. (2005). Gender equality in education: Definitions and measurements. International Journal of Educational Development, $25(4$ SPEC. ISS.), 395-407. https://doi.org/10.1016/j.ijedudev.2005.04.003

Undang-Undang Nomor 20 Tahun 2003 tentang Sistem Pendidikan Nasional.

Walby, S. (1994). Is Citizenship Gendered?. Sociology, Vol. 28, No. 2, 379-395. SAGE Social Science Collections.

Wardhani, S. A. (2012). Parameter Kesetaraan Gender dalam Pembentukan Peraturan Perundangundangan. Kementerian Hukum dan Hak Asasi Manusia, Kementerian Pemberdayaan Perempuan dan Perlindungan Anak, dan Kementerian Dalam Negeri. Republik Indonesia

Winaputra, U. (2015). Pendidikan Kewarganegaraan: Refelski Historis-Epistemologis dan Rekonstruksi untuk Masa Depan. Universitas Terbuka. 